\title{
Factors Associated with Knowledge Sharing Capabilities of IT Professionals in Sri Lanka
}

\author{
Prajapathy Dissanayake ${ }^{1}$ and Rajaletchumie Senathiraja ${ }^{2^{*}}$ \\ ${ }^{1}$ Faculty of Graduate Studies, University of Colombo \\ 2 Department of Management and Organization Studies, \\ Faculty of Management and Finance, University of Colombo \\ *Corresponding author: Rajaletchumie Senathiraja, Email: laxumy@mos.cmb.ac.lk
}

\begin{abstract}
Knowledge sharing capabilities are the abilities of the employees to share their knowledge with colleagues and associates. IT professionals play a significant role in organisations as they share their knowledge with others. Although a few scholars in the western context discuss the organizational and technological perspective in employees' knowledge sharing capabilities, a vacuum remains to fill this subject matter in a Sri Lankan context. There are currently minimal and obsolete studies on how personal and organisational factors play an essential role in IT professionals' knowledge sharing capabilities. Therefore, the researchers investigated the personal, organisational, and technological factors in developing IT professionals' knowledge sharing capabilities in Sri Lanka.

The study uses a self-administered questionnaire. The convenience sampling technique applies to collect data. Descriptive analysis, correlation coefficient and multiple regression analysis employ as the analysing techniques. Among the 368 IT professionals in eight ICT companies in the Western province, Sri Lanka, 59.5\% were male, and most of the respondents are in the age group of $31-40$. $44.8 \%$ of the respondents have work experience between 11 and 20 years, while $54 \%$ have obtained their postgraduate education. The findings highlight that IT professionals' level of knowledge sharing capabilities in Sri Lanka is moderately high. Further, It identifies that top management support and knowledge management system quality are critical in the Sri Lankan context. However, the study points outs that organisational rewards and KMS infrastructure are not significantly associated with the knowledge sharing capabilities of IT professionals in Sri Lanka. In addition, the education level and years of working experience acted as moderating variables between IT professionals' factors and knowledge sharing capabilities in Sri Lanka.
\end{abstract}

Keywords: Knowledge sharing capabilities, Knowledge sharing, Organisational rewards, Top management support, Knowledge management system (KMS)

ISSN :2362-0633

(C) Copyright $\quad$ : Faculty of Graduate Studies, University of Colombo 


\section{Introduction}

Even though organisations are becoming knowledge management entity, the industry faces many challenges to compete in the market. Despite this, every manager has to identify, acquire, and manage the required knowledge to ensure effective management and success. As can be seen, many researchers talk about the importance of knowledge management and sharing of knowledge among the organisation's members. Besides, the sources and the availability of information are available for anyone to learn and improve their understanding. However, some people can utilise that opportunity to learn and share. Therefore, this study focuses on people's capabilities in sharing and managing knowledge to solve complex issues that are not well studied.

Within the sphere of Knowledge Management, knowledge sharing has evolved into an integral function in an organisation due to increasing jobhopping trends (Singh, Jain and Ahamad 2011). Organisations will have to face challenges when knowledge is not shared effectively and efficiently. New and transitioning employees require more time and resources to adapt to organisational processes and systems (Kaplan and David, 2006). However, the capability of sharing knowledge is different from one individual to the other (Kim and Lee, 2006). Still, little research to date has focused on understanding employee motivation to share or hoard knowledge, regardless of the resources available such as knowledge management systems or the culture of an organisation that nurtures an environment of recognition and trust.

In this context, a survey carried out by the Information and Communication Technology Agency of Sri Lanka (ICTA) revealed that the overall IT-BPM workforce grew from 82,854 in 2014 to 124,873 in 2018. Further, a preliminary review of the existing literature, as summarised in Table 1, revealed many factors that influence knowledge sharing in an organisation. However, limited, obsolescent research was found in IT professionals' knowledge sharing capabilities in the Sri Lankan context.

The preliminary survey among a limited sample group of IT professionals in Sri Lanka was also carried out at the onset of the research to understand 


\section{IT Professionals in Sri Lanka}

the local IT sector's prevailing knowledge sharing practices. Accordingly, employees are willing to share knowledge among colleagues (As per Figure 1). However, the recognition and rewarding of employees from the organisation for knowledge sharing remains below expectations. Further, the preliminary study revealed that (As shown in Figure 2 and Figure 3), the organisation has given employees opportunities to share their knowledge. According to Figure 4 and Figure 5, IT professionals' willingness to share their knowledge was directly affected by individual and organisational factors such as rewards, career advancement, and innovativeness. Even though the knowledge among members is equal, the organisation's recognition and rewards for knowledge sharing remain below the expected level.

Based on the preliminary survey, IT professionals believed that knowledge sharing is essential, but their knowledge capabilities level not seen as expected. It also observed the impact of IT professionals' background on IT professionals' knowledge sharing capabilities in Sri Lanka. Therefore, the researchers wanted to examine the degree of knowledge sharing capabilities, organisational, technological support for employees' knowledge sharing capabilities in Sri Lanka. Further, this study focuses on how demographic factors such as years of experience and education level play a role in organisational and technological factors and IT professionals' knowledge sharing capabilities in Sri Lanka.

\section{Literature review and Hypothesis Development}

\section{Knowledge Sharing and Knowledge Sharing Capabilities}

The main factors for productions are land, labour and capital. With the change of the economies, knowledge is regarded as the fourth factor, the primary source for sustained competitive advantage (Leonard and Sensiper, 1998). Knowledge should be applied in the context appropriately when we are achieving different tasks in our day to day lives. Davenport and Prusak define knowledge as "A fluid mix of framed experience, contextual information, values and expert insight that provides a framework for evaluating and incorporating new experiences and information" (Davenport and Prusak,1998). The concept of knowledge defined as the human understanding of a specialised field of interest acquired through study and 
experience. (Awad and Ghaziri, 2011). It bases on learning, experience, thinking and familiarity with the specific area. According to Nonaka, Toyama and Konno,2000), knowledge divided into explicit and tacit.

Knowledge sharing is considered the primary knowledge management process and the most significant knowledge management feature (OkyereKwakye, 2011). Davenport (1994) has stated Knowledge Management as apprehending, dispensing and efficiently using knowledge. In past literature, knowledge sharing defined in many ways. Some researchers define. Knowledge sharing is the "provision of task information and know-how to help others and collaborate with others to solve problems, develop new ideas, or implement policies or procedures" (Wang and Noe, 2010). However, Lin (2007) defines knowledge sharing as a culture that interacts in a community with knowledge interchange of the employees' experiences and expertise within a department or an organisation. The same idea is supported by some scholars (Kim and Lee, 2006). Accordingly, Knowledge sharing capability is defined as employees' ability to share their work-related experience, expertise, know-how, and contextual information with other employees through informal and formal interactions within or across teams or work units.

In another way, knowledge sharing capability is defined by Kim and Lee (2006) as an employee's capability to obtain the knowledge held by other departments in the same organisation. A study was done on employee knowledge sharing capabilities in Malaysia's electronic agencies (Noor and Salim, 2011). Further, Kim and Lee (2004) identified that organisational factors affect South Korean E-Government knowledge-sharing capabilities. This evidence also showed that public sector organisations played a vital role in knowledge-sharing capabilities by distributing individual employees' work-related experience and cooperation between themselves and the organisation's subsystems. Meantime some scholars (Kanaan, 2013; Masa'deh, Gharibeh, Maqableh \& Karajeh,2013) studied the knowledge sharing capabilities of Jordanian telecommunication firms' employees identified that enjoyment in helping others, top management support, and organisational rewards, and ICT usage as the knowledge sharing enablers.

According to Masa'deh, Gharibeh, Maqableh \& Karajeh (2013), knowledge sharing capabilities support creativity and innovation and improve firm performance. In the new knowledge economy, IT professionals are essential, 


\section{IT Professionals in Sri Lanka}

and they play a significant role within the organisation context of tacit knowledge management (Borges, 2012). According to Borges (2012), knowledge management, organisational learning and knowledge transfer are essential IT professionals' activities. Sometimes IT professionals play the role of knowledge brokers in the organisation because the knowledge is transferred in two contexts across the organisation; one way is shared knowledge between the IT professionals and users and between users in the different business unit (Pawlowski and Robey, 2004). Further, Niederman, Sumner \& Maertz (2007) explained that IT professionals are the leading players. They transform the ordinary transaction processes into strategic initiatives in current trades by designing, implementing, and maintaining infrastructure and applications. The individual's conscious effort to share or not share the knowledge will determine the creation and sharing of knowledge. The decision to share the knowledge may depend on the individual's capability of sharing knowledge. In the Sri Lankan context, minimal studies have been performed on knowledge sharing capabilities and few studies on knowledge sharing (Dharmasiri and Kodeeswaran, 2011; Pushpamali, 2015; Ranasingh and Gamini, 2008; Wickramasinghe and Widyaratne, 2012). Therefore, it is vital to understand the factors associated with knowledge sharing capabilities and knowledge sharing to proceed with the study. The following section will review the necessary literature to understand the factors associated with knowledge sharing capabilities.

\section{Organisational context and Knowledge Sharing Capabilities}

There are different factors of organisational dimension, which will influence knowledge sharing capabilities positively or negatively. According to Lin (2007), there are different aspects of organisational climate in knowledge sharing, which behave as critical drivers. Further, Lin (2007) states that open leadership climate and top management support are critical drivers of knowledge sharing in his study rewards systems. Kim and Lee (2004) discuss the relationship between the vision and goal, trust, social networks, organisational culture, structuration, and performance-based reward systems. Kaewchur and Phusavat (2016) have revealed that organisational culture, organisation structure, and organisation environment are associated with knowledge sharing. This study will focus only on the organisational rewards and top management support as determinants of knowledge sharing capabilities in the organisational context. 


\section{Organisational Reward}

According to Ong and Teh (2012), the reward is a benefit that the organisation provides to an employee. Davenport and Prusak (1998) have pointed out that organisation rewards could be in two types, monetary incentives and non-monetary awards. The salary and bonuses are examples of economic incentives and promotions and job security examples for nonmonetary awards. Further, Bartol and Srivastava (2002) describe financial reward as bonuses and non-monetary rewards as dinner gift vouchers, awards, public recognition etc. In this study, the organisational rewards construct is derived from the Social Exchange Theory (SET). SET is defined as the "voluntary actions of individuals that are motivated by the returns they are expected to bring and typically do bring from others"(Blau, 1964). In Social Exchange Theory (SET), two parties are expected to be benefited by exchanging a valuable resource (Razak, Pangil, Zin, Yunus \& Asnawi, 2016). Emerson (1976) explained that SET suggested an individual perform a specific action if the individual is rewarded more often for that particular action. Therefore, according to social exchange theory, IT professionals will be rewarded by the organisations to share their knowledge with others. It is a way of exchanging knowledge and rewards. Kanaan (2013) claimed that Jordanian telecommunication firms proved that organisational rewards act as a knowledge-sharing enabler on knowledge sharing capabilities. It indicated that it would motivate employees to generate new knowledge, share the existing knowledge, and happily help other colleagues in different divisions when organisations implement organisational reward systems.

Al-Busaidi, Olfman, Ryan and Leory, (2010) also claimed that the reward would be the main factor for knowledge sharing in knowledge management systems because it is contributed by the employees' creation and codification of their knowledge in the knowledge management systems other employees to use. The main functions of having a performance-based reward system are to increase the participation and communication of all the units in an organisation. The information on the performance of organisational units' actions, procedures, products and services will be collected, processed and delivered (Neely, 1998). Further, it proved that the performance-based reward system positively influences the employees' knowledge sharing capabilities in the public sector and private sector organisations in South Korea (Kim and Lee, 2006). The study of Kim and Lee (2004) also explored 


\section{IT Professionals in Sri Lanka}

how a performance-based reward system will influence the employees' knowledge sharing capabilities in the E-government sector of South Korea. It was evident in the above study that the knowledge sharing capabilities of the South Korean government employees will be at a higher level when the rewards system established in organisations.

Additionally, Masa'deh, Gharibeh, Maqableh \& Karajeh (2013) affirmed that the organisations' rewards system influenced the employees' knowledge sharing capabilities in the telecommunication firms and acted as a knowledge-sharing enabler. Several researchers have found that there is a relationship between knowledge sharing and organisational rewards. Tan (2016) has proven a significant positive relationship between organisational rewards and knowledge sharing among Malaysia's academics. Another study performed among academics has recognised that organisational rewards positively influence knowledge sharing (Singh, Jain \& Ahamad 2011). Abdul-Cader and Johar (2015) have identified in their study, which was performed among the Sri Lankan IT professionals, that there is a positive relationship between knowledge sharing and organisational rewards. Employees with reward systems in their organisations tend to share their knowledge, and previous studies showed a positive relationship between the organisational rewards and knowledge sharing capabilities (Kanaan, 2013; Kim and Lee, 2006; Masa'deh, Gharibeh, Maqableh \& Karajeh, 2013). Tan (2010) identified a positive relationship between knowledge sharing and the reward system in the banking sector of Malaysia. Based on the literature review, we put forward the following hypotheses:

H1: Organisational rewards influence knowledge sharing capabilities of IT professionals in Sri Lanka.

\section{Top management Support}

Top management reflected as one of the significant possible influences on an organisation's knowledge (Connelly and Kelloway, 2003). Lee, Shiue \& Chen (2016) considered top management in their study and claimed that a person or a team with a few essential persons would impact the employees' views and willingness to complete a task. Top management support is a factor that has been studied widely as an enabler of knowledge sharing context (Asrar-ul-Haq and Anwar, 2016). 
One of the major theories used in social, environmental and sustainability management research is stakeholder theory (Hörisch, Freeman \& Schaltegger., 2014). The stakeholder theory's central concept is defined as "the organisation must manage and integrate the relationships and interests of stakeholders to ensure successful organisational outcomes" (Freeman, 2010). Freeman (1984) has defined a stakeholder as a set of individuals in an organisation who can impact or be impacted by accomplishing the organisation's objectives. Managing stakeholders' relationships focuses on Stakeholder Theory (Hörisch, Freeman \& Schaltegger., 2014). Top management support will help to manage the relationship of the stakeholder (Huang, 2015). Therefore, the top management support variable is derived from the Stakeholder theory.

Lin (2006) stated that top management support is vital to create a helpful environment and make available adequate resources. Numerous studies on knowledge sharing in different sectors have found that top management positively influences knowledge sharing (Hejase, 2014; Lin, 2007; Tan, 2016a). Asrar-ul-Haq and Anwar (2016) stated that top management support identified as a significant enabler of sharing knowledge. Top management support helps increase the level and value of knowledge sharing by persuading the employees' commitment (Wang and Noe, 2010).

Further, Lee, Shiue \& Chen (2016) stated in their study that the top management should be the role model of sharing the knowledge in the organisation. However, the sharing of knowledge could be encouraged through training and providing reward schemes or resources. Top management support is a knowledge sharing enabler that increases Jordan's telecommunication firms (Kanaan, 2013). Jain, Sandhu \& Sidhu (2007) emphasised that the employees would like to share their knowledge if the top management gave proper support.

According to the study performed by Masa'deh, Gharibeh, Maqableh \& Karajeh (2013), among Jordanian telecommunication firms' employees, it was evident that the top management support influenced knowledge sharing capability positively. According to the previous literature, there could be so many ways the top management could influence the employees to share their knowledge among themselves. Top leadership needs to have award ceremonies to appreciate the employees who willingly share their knowledge (Lin, 2007). 


\section{IT Professionals in Sri Lanka}

Findings by Hejase (2014), Lee, Shiue \& Chen (2016), Lin (2007) show that top management support has a positive influence on sharing knowledge among employees. Past research conducted among academics shows no significant relationship between top management support and academic knowledge (Tan, 2016a). Further, some of the previous studies that Kanaan performed have proved a significant influence between the Jordanian telecommunication industry employees' top management support and knowledge-sharing capabilities. No studies have analysed the effect of toplevel management on knowledge sharing capabilities in the Sri Lankan context. Accordingly, we hypothesis,

H2: Top management support influences knowledge sharing capabilities of IT professionals in Sri Lanka.

\section{Technological Context and Knowledge Sharing Capabilities}

According to the past, research technology plays a significant role as one of the determinants in the knowledge sharing process (Al-Busaidi, Olfman, Ryan \& Leory, 2010; Hejase, 2014; Tan 2016a). Technology is the main component that helps to share the knowledge within an organisation, and it allows the employees to use accurate information at the correct time (Hejase, 2014). Technology enables the flow of information by designing and implementing systems that help communicate, collaborate, and distribute knowledge. In this study, knowledge management systems infrastructure and knowledge management system quality will be considered factors associated with IT professionals' knowledge sharing capabilities in Sri Lanka under the technological context.

\section{Knowledge Management System Infrastructure}

The term 'knowledge management system infrastructure' referred as "the information technologies that allow knowledge management related activities, such as web-based storage, virtual communities, internet, intranet, groupware, video conferencing, group support systems, distance education tools, online group discussion, portal technology, instant messaging and email" (Lin, 2011). Knowledge management infrastructure helps to capture and share knowledge among the employees by allowing shared access to information. The communication level would increase, and the employees' 
social networking would enhance through knowledge management system infrastructure. Resource-Based View (RBV) theory explains how sustainable competitive advantage could be gained by using the organisation's resources (Barney, 1991). Further Barney, (1991) suggests in RBV that different capabilities are used to transform the resources into outputs of more excellent value, and the capability could be skills (e.g., managerial ability) or processes such as knowledge sharing (Pee and Kankanhalli, 2009). RBV makes it available for researchers to understand the role of information systems within the firm. It helps discover how particular parts of the firm, such as product development practices, knowledge management capabilities, etc., will affect the firm and sustain competitive advantage (Wade and Hulland, 2004). Scholars have defined a knowledge management system as " a system that provides for the creation of new knowledge, the assembly of externally created knowledge, the use of existing knowledge, and the finding of knowledge from internal and external sources" (Meso and Smith, 2000). Thereby based on the concept of capability in RBV, KMS can be an organisation's ability to improve knowledge management (Pee and Kankanhalli, 2009). Knowledge management system infrastructure and knowledge management system quality could be explained from RBV theory; therefore, the knowledge management system is considered an organisational resource that will sustain competitive advantage through innovation.

According to Connelly and Kelloway (2003), knowledge management system infrastructure permits easy access among the employees to share their knowledge. A study performed among Malaysian universities' academics proved no relationship between knowledge sharing and knowledge management system infrastructure (Tan, 2016a). The amount of knowledge contributed to a knowledge management system is crucial in deciding the breadth and depth of the knowledge management system (AlBusaidi, Olfman, Ryan \& Leory, 2010). Further, scholars (Alavi and Leidner, (2001); Davenport and Prusak (1998)) explain in their studies that the repository knowledge management system is one of the traditional methods as well as the most popular way to develop the organisational knowledge management system.

As Alavi and Leidner (2001) describe, the knowledge management system will help establish the organisation memory, which helps store the 


\section{IT Professionals in Sri Lanka}

organisation's explicit and articulated knowledge efficiently. The knowledge sharing process will be sped up and increased for the newcomers of an organisation when a repository knowledge management system used will help transmit the cultural rituals and routines in the organisations (Davenport and Prusak 1998). Kim and Lee (2006) found out that public and private employees of South Korea utilise IT applications such as internet-based services, intranets, electronic data management systems and knowledge management systems to share their knowledge in the organisations. Further, the same study discovered that the private employees' usage level of IT applications is higher than the public employees. According to the research statistics, the remote employees' knowledge sharing capability is significantly higher than the public employees.

Additionally, it showed that an employee's level of knowledge sharing increased when the information system is user-friendly. With the research findings, Kim and Lee (2006) proved that employees' utilisation of IT application positively affects knowledge-sharing capabilities. Therefore, knowledge management system infrastructure plays an essential role in improving the capabilities of employees in organisations. Xue and Zhang (2010) revealed a significant influence between knowledge sharing and knowledge management system infrastructure. Thus, so far, no studies have been conducted on the effect of knowledge management system infrastructure on knowledge sharing capabilities. The researchers formulate the following hypothesis:

H3: The Knowledge management system infrastructure influences knowledge sharing capabilities of IT professionals in Sri Lanka.

\section{Knowledge Management System Quality}

According to the Information System Success Model presented by DeLone and McLean (2003), system quality is one of the independent variables for a successful information system. Al-Busaidi, Olfman, Ryan \& Leory (2010) consider system quality as the easiness, rapidity, comprehensiveness, and efficiency when storing and uploading knowledge management systems. They state that employees encouraged to share knowledge among themselves; the knowledge management system should consist of proper functions and excellent qualities (Alavi and Tiwana, 2002). Kulkarni and 
Ravindran 2007 claimed that to use a knowledge management system such as retrieving, storing, searching etc. and the system should have qualities such as availability and user-friendliness. As shown in current literature, many studied the influence of knowledge management system quality with knowledge sharing (Al-Busaidi, Olfman, Ryan \& Leory, 2010; Ho and Kuo, 2013; Tan, 2016a). However, limited research is conducted on knowledge management system quality and the knowledge sharing capabilities of IT professionals. When the system is supposed to be easy to use, it may also be assumed to be high quality; thus, easiness of using a plan will be a sign of system quality (Nelson, Todd \& Wixom., 2005). The quality of the knowledge management system is significant for an individual's contribution since its effectiveness and efficiency will help perform the storage and upload function successfully (Al-Busaidi, Olfman, Ryan \& Leory, 2010). According to this study, the system's high quality impacts the individual contribution to the organisation. These scholars also argued that the knowledge sharing process would be easy and quick when the system's quality is high. Contrastingly Ho and Kuo (2013) identified that system quality does not significantly impact online knowledge sharing. According to Nelson, Todd \& Wixom. (2005), there are five critical dimensions to system quality: response time, accessibility, reliability, flexibility, and integration. Further, Tan ( 2016), in her research among academics, found out that there is a positive relationship between knowledge sharing and knowledge management system quality. In the meantime, Al-Busaidi, Olfman, Ryan \& Leory (2010) also have proved that knowledge management system quality positively influences knowledge sharing. Therefore, the quality system of management may impact the knowledge sharing of the professional in the IT sector. Based on these literatures, the researchers developed the below hypothesis,

H4: Knowledge management system quality influences knowledge sharing capabilities of IT professionals in Sri Lanka. 


\section{IT Professionals in Sri Lanka}

\section{Moderating Role of Demographical Context of Knowledge Sharing Capabilities}

Numerous factors impede knowledge sharing capability among employees, and one of the elements is demography (Ismail and Yusof, 2009). Several studies performed to determine how demographic factors influence knowledge sharing in organisations (Ismail and Yusof, 2009; Kim and Lee, 2006), but a minimal number of studies to find the influence between IT professionals' demographic factors and knowledgesharing capabilities in Sri Lanka. Many scholars explained many demographic variables studied, such as age, level of education, gender, ethnicity, job position, years of work experience, sector etc. (Ismail and Yusof, 2009; Kim and Lee, 2006). Kim and Lee, 2006) studied how demographic variables such as years of work, position, education, and the sector will influence knowledge sharing capabilities in the public sector. The level of education also reported that it does not affect knowledge sharing among software engineering development managers (Ojha, Abhoy K., 2005). Noor and Salim (2011) demonstrated that the employees with a higher level of education like to share their knowledge than the employees who have a lower level of education.

An empirical study done in telecommunication firms in Jordan revealed a significant impact on knowledge sharing capabilities due to the employees' experience and education level (Kanaan, 2013). Kim and Lee (2006) have identified that the level of education and years of work experience positively influence knowledge sharing capabilities in employees of public-sector and private-sector organisations in South Korea. However, no studies to find the moderating role of the IT professionals' demographic factors between organisational, technological factors and knowledge-sharing capabilities of IT professionals in Sri Lanka. Thus, the following alternative hypotheses were developed based on this existing literature.

H5: The education level moderates the relationship between IT professionals' organisational rewards and knowledge sharing capabilities in Sri Lanka.

H6: The work experience moderates the relationship between IT professionals' organisational rewards and knowledge sharing capabilities in Sri Lanka. 
H7: The education level moderates the relationship between top management support and knowledge sharing capabilities of IT professionals in Sri Lanka.

H8: The work experience moderates the relationship between top management support and knowledge sharing capabilities of IT professionals in Sri Lanka.

H9: The education level moderates the relationship between knowledge management system infrastructure and IT professionals' knowledge sharing capabilities in Sri Lanka.

H10: The years of work experience moderates the relationship between knowledge management system infrastructure and knowledge sharing capabilities of IT professionals in Sri Lanka.

H11: The education level moderates the relationship between knowledge management system quality and knowledge sharing capabilities of IT professionals in Sri Lanka.

H12: The years of work experience moderate the relationship between knowledge management system quality and knowledge sharing capabilities of IT professionals in Sri Lanka.

\section{Conceptual Model and Operationalisation}

Based on the above hypotheses, the conceptual model in figure - 6 is drawn and tested in the next section. The conceptual model in Figure 6 explains the relationship between IT professionals' organisational, technological and knowledge-sharing capabilities in Sri Lanka. The variables such as organisational rewards and top management support, knowledge management system infrastructure and knowledge management system quality as the independent variables. The dependent variable of the conceptual model is the knowledge sharing capabilities of IT professionals in Sri Lanka. Level of education and years of work experience are the demographic factors considered as moderating variables. Demographical factors were evaluated according to the existing literature, as discussed in the previous section. Table 2 has explained the items used to operationalise the study of the construct. 


\section{Methods}

According to the national IT-BPM workforce survey 2019 performed by ICTA (Information and Communication Technologies Agency), the total workforce of ICT in Sri Lanka estimated to be about 124,873 (National IT-BPM Workforce Survey 2019, 2019). The ICT workforce (124,873) represented by major workforce categories comprising ICT, non-ICT, Government, BPO and training in Sri Lanka. The current research targeted the IT professionals in Sri Lanka, and this study considered IT professionals who employed in the ICT companies in the Western province of Sri Lanka. Therefore, the study's total population is the workforce strength of IT professionals in ICT companies in Sri Lanka, 81,741 (National IT-BPM Workforce Survey 2019, 2019). The determined sample size of the study is 383 , according to the table by Krejcie and Morgan (1970). The research conducted on a convenience sampling method because the sample selected based on the accessibility of the individuals who represent the population. The quantitative method followed throughout the research.

In this study, a self-administered questionnaire was used as the data collection method. The questionnaire was a web-based survey. The hypotheses were tested by collecting the primary data through a questionnaire developed based on previously tested instruments (DeLone and McLean, 2003; Kim and Lee, 2006; Lee and Choi, 2003; Lin, 2007; Tan, 2016a; Tan and Zhao, 2003). The questions were amended to suit the current study. The instrument was developed to gather the perceptions of IT professionals on knowledge sharing capabilities (Kim and Lee, 2006; Tan, 2016a), top management support (Lin, 2007,2011), organisational rewards(Lin, 2007), knowledge management systems (Tan, 2016a)and demographic information such as years of work experience etc. (Kim and Lee, 2004). For each question, a five-point Likert scale was used to measure the participants' feedback. The Likert scale includes "Strongly Agree", "Agree", "Neutral", "Disagree", to "Strongly Disagree". The respondents indicated the degree of their agreement or disagreement for each question. The validity and reliability were retested. An email that links to the questionnaire was sent to several ICT companies that agreed to participate in the study. Data collected from IT professionals in the Western province since it is the province with the highest number of IT professionals in Sri Lanka (Labour Force Survey - Annual Report, 2018). 


\section{Data Analysis}

For the main study, four hundred questionnaires were sent for the data collection, and the determined sample size is 383 - a total of 368 responses received from the eight companies. The response rate of the current study was 92\%. Among the 368 respondents, 219 (59.5 per cent) were male. Respondent's age ranged from the 20 s to over 50 s, with 52.4 per cent over 30. 44.8 per cent of the respondents had $11-20$ years of working experience, and 34.2 per cent were degree holders. Descriptive analysis, Correlation coefficient and Multiple regression analysis ( Saunders, Lewis \& Thornhill, 2009) found the relationships between the variables. Data analysed by using the SPSS software (Saunders, Lewis \& Thornhill, 2009).

\section{Validity and reliability}

Kaiser-Meyer- Olkin Measure of Sampling Adequacy (KMO) value is 0.925, which is above 0.7; therefore, according to Kaiser (1974), the sample was adequate for factor analysis. Additionally, Bartlett's Test of Sphericity value is significant as 0.000 , which is less than 0.05 (Pallant, 2011). Therefore, it verified that the data set was suitable for factor analysis. The items used to operationalise the constructs were used from previous studies and adapted according to this study. The reliability test performed for each variable, and accordingly, the value of Cronbach's Alpha for each variable was more significant than 0.7 (Cronbach, 1951), which showed a perfect internal consistency (Pallant, 2011).

\section{Correlation Analysis}

The results of the correlation analysis were shown in Table 3 . The strength and direction of the linear relationship between variables were described using Pearson's product-moment correlation coefficient (PMCC) (Arkkelin, 2014; Saunders, Lewis \& Thornhill, 2009). The findings of Table 3 describe the correlation between the dependent variable (knowledge sharing capabilities) and the independent variables (organisational rewards, top management support, knowledge management system infrastructure and knowledge management system quality). Initial analyses carried out to confirm no violation of the assumptions of normality, linearity, and homoscedasticity. The findings in Table 3 , it is evident that organisational 


\section{IT Professionals in Sri Lanka}

and technological factors positively correlate with IT professionals' knowledge sharing capabilities in Sri Lanka.

\section{Standard Multiple Regression Process}

Multiple regression analysis was conducted based on correlation analysis to explore the relationships between continuous and independent variables (Pallant, 2011). According to Pallant (2011), the standard multiple regression process tests some of the hypotheses. The hierarchical multiple regression process was used to find moderated variables on the relationship between the dependent and independent variables. As per Table 4, the Beta value (Standardised Coefficients) and a significance level of the independent variables in the model will help to compare the contribution of each independent variable,

\section{Hierarchical Multiple Regression Analysis with Moderate Variables}

Table 5 presents the hierarchical multiple regression procedure results, determining how the moderate variables will influence the relationships between the independent variables and the study's dependent variable (Pallant, 2011).

\section{Hierarchical Multiple regression with Degree level, Postgraduate Diploma level, less than ten years of work experience and more than ten years of work experience}

According to the study's response rate, the degree level taken as the primary education and the postgraduate diploma was taken as the higher education level to compare how the higher education level moderates the relationships between the factors and knowledge-sharing capabilities. Table 6 compares the respondents' coefficient values, who have less than ten years of work experience with more than ten years of work experience.

\section{Discussion}

The sample characteristics analysis reveals that the majority of the respondents were males. According to the statistics, 219 were males out of the total respondents of 368. Most of the respondents were in the age category of $31-40$. Years of work experience show that most respondents have 11 to 20 years of work experience and very few respondents $(6 \%)$ have 
less than five years' experience. It observed that most of the respondents (34\%) had completed their primary degree, while $30 \%$ of the respondents have completed their postgraduate diploma.

The level of knowledge sharing capabilities of IT professionals in Sri Lanka was measured as one of the study's objectives. The willingness to share an individual's knowledge evaluated and showed that IT professionals in Sri Lanka share their knowledge as the mean value is 4.33 . According to the current study, the overall mean value, which is 4 , understood that IT professionals' knowledge sharing capabilities in Sri Lanka are moderately high. Scholars such as Kanaan (2013); Kim and Lee (2004, 2006); Masa'deh, Gharibeh, Maqableh \& Karajeh,2013; Noor and Salim (2011) have performed studies on knowledge sharing capabilities in different sectors such as public administration, private industry, telecommunication etc., but a minimal number of studies conducted in the Sri Lankan IT sector. In their study, Kim and Lee (2006) have found that the level of knowledge sharing capabilities of the private sector employees in South Korea is high. In another study performed by Kanaan (2013) in Jordan's telecommunication sector, the overall mean value of the employees' knowledge sharing capabilities is 3.7 , closer to the current study mean value of knowledge sharing capabilities though the sector is different. According to the recent research results, the Sri Lankan IT professionals' capability to share knowledge is moderately high.

According to the hypothesis (H1), organisational rewards influence knowledge sharing capabilities of IT professionals in Sri Lanka is not accepted since it was not statistically significant. However, the regression coefficient value was positive. Therefore it evidences that organisational rewards will not influence the level of knowledge sharing capabilities of IT professionals in Sri Lanka, which is contradicting some of the other studies ( Al-Busaidi, Olfman, Ryan \& Leory, 2010; Kanaan, 2013; Kim and Lee, 2004, 2006; Masa'deh, Gharibeh, Maqableh \& Karajeh,2013). These studies have revealed that organisational rewards influence knowledge sharing capabilities in different sectors. Scholars Kim and Lee (2006) have identified that organisational rewards help increase sharing employees' knowledge. According to the current study, rewards may not be proportionated to the Sri Lankan IT professionals' contribution and must be not valued properly for sharing the knowledge with others, as Han and Anantatmula (2007) 
explained in their study. Thereby, it understood that sharing the Sri Lankan IT professionals' knowledge is less likely with the organisations' current reward systems.

The hypothesis (H2) was formulated to find top management support on IT professionals' knowledge sharing capabilities in Sri Lanka, which accepted according to the regression analysis. It revealed that top management support positively and significantly correlated with IT professionals' knowledge sharing capabilities in Sri Lanka. According to the findings of the existing literature ( Al-Busaidi, Olfman, Ryan \& Leroy, 2010; AlHusseini and Dosa, 2017; Asrar-ul-Haq and Anwar, 2016; Han and Anantatmula, 2007; Hejase, 2014; Jain, Sandhu \& Sidhu,2007; Kanaan, 2013; Lin, 2007; ( Masa'deh, Gharibeh, Maqableh \& Karajeh,2013; Tan, 2016a), it was evident that top management support influences the capability of sharing the knowledge. Furthermore, Kanaan (2013) has identified top management support as an enabler that increases knowledge sharing capability in Jordanian telecommunication companies.

The study results revealed that IT professionals' knowledge sharing capabilities in Sri Lanka would positively influence top management's knowledge sharing encouragement. Hence, it proved that Sri Lankan IT professionals are more likely to express high knowledge-sharing capabilities when top management support is received.

Based on the hypothesis (H3), KMS infrastructure influenced IT professionals' knowledge sharing capabilities in Sri Lanka and rejected the regression analysis results. The multiple regression analysis performed with other factors observed that there is no statistical significance. Thereby, the knowledge management system infrastructure does not influence IT professionals' knowledge sharing capabilities in Sri Lanka. There are limited studies that have discussed the relationship between IT professionals' KMS infrastructure and knowledge sharing capabilities. Nevertheless, there are few studies that Tan (2016b), Tan and Noor (2013) had performed in the academic sector, which confirmed that the knowledge management system infrastructure does not influence sharing. Thereby with the results of this study, it is evident that the accessibility of the KMS, communication level of the KMS, searching ability of the KMS and collaboration of the KMS are not an expected level to help IT professionals to share their knowledge. Tan 
(2016b) explains in her study that a good KMS infrastructure should identify, capture and transfer tacit knowledge of the persons to facilitate the transference of tacit understanding among the employees. Thereby, with the results, it is understood that the ability to share the Sri Lankan IT professionals' knowledge is less likely with the current infrastructure of KMS in the organisations.

KMS quality influences knowledge sharing capabilities of IT professionals in Sri Lanka, which is the H4 hypothesis. It accepted according to the results of the regression analysis. The findings stated that the knowledge management system quality has a significant and positive relationship with IT professionals' knowledge sharing capabilities in Sri Lanka. This result is not consistent with Ho and Kuo's (2013) findings where it states that a knowledge management system quality does not influence knowledge sharing capabilities. However, the previous research (Al-Busaidi, Olfman, Ryan \& Leory,2010; Tan, 2016) also proves that knowledge management system quality influences knowledge sharing. Furthermore, it is evident with accepting hypothesis $\mathrm{H} 4$ that the quality of the KMS will help increase the knowledge sharing capabilities of IT professionals in Sri Lanka. The Sri Lankan IT professionals are more likely to express their knowledge-sharing abilities when the KMS has a high-quality level, such as accuracy, availability, dependability, and knowledge relevance.

Therefore, top management support and KMS quality are associated significantly with IT professionals' knowledge sharing capabilities in Sri Lanka.

The level of education and the years of work experience are the moderating variables selected to find the influence of demography factors on the relationship between the factors influencing knowledge sharing capabilities and knowledge sharing capabilities of IT professionals in Sri Lanka.

It was evident that the level of education and the years of experience act as moderators on the relationships between IT professionals' knowledgesharing capabilities in Sri Lanka and organisational rewards according to hypotheses H5 and H6. There are limited studies about education and years of experience influencing the relationship between knowledge sharing capabilities and organisational rewards. Nevertheless, with the existing 


\section{IT Professionals in Sri Lanka}

literature (Ismail and Yusof, 2009; Kim and Lee, 2006), it was found that the level of education influences knowledge-sharing capabilities. On the other hand, Pangil and Nasurdin (2008) verified no influence between education and knowledge sharing. Previous studies (Ismail and Yusof, 2009; Kim and Lee, 2006; Noor and Salim, 2011) found that the years of work experience influenced knowledge-sharing capabilities. Pangil and Nasurdin (2008) also showed no influence between work experience and knowledge sharing. However, the current study's finding shows a positive relationship between work experience and knowledge sharing. Further, Kanaan (2013) revealed a significant influence of organisational rewards on the knowledge-sharing capabilities of the Jordanian telecommunication industry employees in favour of education level and years of experience.

As per hypotheses $\mathrm{H} 7$ and $\mathrm{H} 8$, the level of education and the years of experience act as moderators on the relationship between top management support and knowledge sharing capabilities of IT professionals in Sri Lanka. There are limited studies to find how the level of education and the number of years will influence the relationship between top management support and knowledge sharing capabilities of IT professionals in Sri Lanka. However, past studies (Ismail and Yusof, 2009; Kim and Lee, 2006) have identified education and years of experience positively influencing knowledge sharing capabilities and knowledge sharing. Additionally, the study of Tan and Trang (2017) revealed that the level of education and years of experience would positively influence knowledge sharing, which contradicts Pangil and Nasurdin's (2008) study. At the same time, Kanaan (2013) revealed a significant influence of top management support on the employees' knowledge sharing capabilities in the Jordanian telecommunication industry, favoring education level and years of experience.

Hypotheses, H9, H10, H11, and H12 indicated that education and years of experience played as moderators on the relationship between knowledge management system (infrastructure and quality) and IT professionals' knowledge-sharing capabilities in Sri Lanka respectively. The education level strongly influences the relationship between KMS infrastructure and IT professionals' quality and knowledge-sharing capabilities in Sri Lanka. In the previous studies (Ismail and Yusof, 2009; Kim and Lee, 2006; Noor and Salim, 2011), education and years of experience influence knowledge sharing capabilities when information technology acts as a knowledge- 
sharing enabler. However, minimal studies are in the literature on the demographic factors and knowledge sharing capabilities when the KMS infrastructure and quality service are knowledge-sharing enablers.

From the above results, it discovered that demography factors (the level of education and the years of experience) play the moderating role in the relationship between the elements (organisational rewards, top management support, KMS infrastructure and KMS quality) and knowledge-sharing capabilities of the IT professionals in Sri Lanka. Further, it proved that IT professionals who have a high level of education and more work experience would have a high capability to share their knowledge.

\section{Conclusion}

The study determines the level of IT professionals' knowledge sharing capabilities in Sri Lanka. Further researchers examined the relationship between factors associated with IT professionals' knowledge sharing capabilities in Sri Lanka. The research based on a survey of 368 IT professionals from IT companies in the Western province of Sri Lanka. This study revealed that IT professionals' level of knowledge sharing capabilities in Sri Lanka is moderately high. Further, it was evident that top management support and knowledge management system quality will significantly influence IT professionals' knowledge sharing capabilities in Sri Lanka. It also confirmed that the level of education and the years of experience are moderating variables on the relationship between factors (organisational rewards, top management support, KMS infrastructure and KMS quality) and knowledge-sharing capabilities of IT professionals in Sri Lanka.

Additionally, the results proved that the ability to share the knowledge would increase when the level of education and the years of experience of IT professionals in Sri Lanka are higher than the others. However, this study has confirmed that IT professionals' knowledge sharing capabilities do not significantly influence organisational rewards and knowledge management system infrastructure in Sri Lanka. The existing literature observed many studies performed globally and Sri Lankan context on knowledge sharing and knowledge sharing capabilities in different sectors. Still, microscopic research are conducted on knowledge sharing capabilities of IT professionals in Sri Lanka. Hence the current study will support filling the literature gap too. Knowledge sharing is an essential process in organisations. It is vital to 


\section{IT Professionals in Sri Lanka}

understand the factors associated with IT professionals' knowledge sharing capabilities in Sri Lanka. The data collection is limited to IT professionals based in Western province. Time and budget-constrained were found during the data collection of the study. This research did not consider all the factors which will be associated with knowledge sharing capabilities.

The results highlighting the essence of top management's commitment, and it should always support and encourage employees to share their knowledge with colleagues by providing necessary resources (System infrastructure etc.). Further, it facilitates opportunities to share employees' knowledge and gain new knowledge (Brainstorming sessions, Tech talks, workshops, seminars, training, conferences, etc.). ICT companies should always retain top IT talent with high educational qualifications and experience by providing rewards, recognition, and growth opportunities.

It is evident that the findings and the limitations mentioned in the previous sections that the research results can differ from the other studies due to the factors such as the population, period of the research etc. Thereby, future studies would focus on how IT professionals' knowledge sharing capabilities will influence other aspects of organisational factors such as corporate culture, organisational structure, etc. Further, individual characteristics such as trust, knowledge, self-efficacy, reciprocal benefits etc. and demographic factors such as age, gender, job position etc., should be considered in future. In future studies, the population could be taken as the total workforce of ICT in Sri Lanka, and samples could be taken from the other Sri Lanka provinces. This research should also be extended to different sectors, such as administration, academic, banking, etc.

\section{References}

Abdul-Cader, K. M., \& Johar, G. (2015). A Study of Knowledge Seeking through Electronic Knowledge Repositories among Sri Lankan IT Professionals. International Journal of Emerging Trends \& Technology in Computer Science (IJETTCS)4(6), 10.

Alavi, M., \& Leidner, D. E. (2001). Review: Knowledge Management And Knowledge Management Systems: Conceptual Foundations and Research Issues. MIS Quarterly, 25(1), 107. https://Doi.Org/10.2307/3250961 
Alavi, M., \& Tiwana, A. (2002). Knowledge Integration in Virtual Teams: The Potential Role of KMS. Journal of the American Society for Information Science and Technology, 53(12), 1029-1037. https://Doi.Org/10.1002/ Asi.10107

Al-Busaidi, K. A., Olfman, L., Ryan, T., \& Leroy, G. (2010). Sharing Knowledge to a Knowledge Management System: Examining the Motivators and the Benefits in an Omani Organisation. Journal of Organisational KM. http://www.ibimapublishing.com/journals/JOKM/ jokm.html

Al-Husseini, S. J., \& Dosa, T. A. (2017). Top Management Support as an Enabling Factor for Academic Innovation through Knowledge Sharing. World Academy of Science, Engineering and Technology International Journal of Educational and Pedagogical Sciences.11(8), 7.

Arkkelin, D. (2014). Using SPSS to Understand Research and Data Analysis. Psychology Curricular Materials. Book 1. http://scholar.valpo. edu/psych_oer/1.195.

Asrar-Ul-Haq, M., \& Anwar, S. (2016). A Systematic Review of Knowledge Management and Knowledge Sharing: Trends, Issues, and Challenges. Cogent Business \& Management, 3(1). https://Doi.Org/10.1080/23311975. 2015.1127744

Awad, M., \& Ghaziri, H. (2011). Knowledge-Management-By-Elias-M-AwadHassan-MGhaziri.Pdf.https://Yukikolouisdodd.Files.Wordpress.Com/2017/05/ Knowledge-Management-By-Elias-M-Awad-Hassan-M-Ghaziri.Pdf

Barney, J. (1991). Firm Resources And Sustained Competitive Advantage. Journal of Management, 17(1), 99-120. https://Doi.Org/10.1177/ 014920639101700108

Bartol, K. M., \& Srivastava, A. (2002). Encouraging Knowledge Sharing: The Role of Organisational Reward Systems. Journal of Leadership \& Organisational Studies, 9(1), 64-76. https://Doi.Org/10.1177/ 107179190200900105

Bock, Zmud, Kim, \& Lee. (2005). Behavioral Intention Formation in Knowledge Sharing: Examining the Roles of Extrinsic Motivators, Social-Psychological Forces, and Organisational Climate. MIS Quarterly, 29(1), 87. https://Doi.Org/10.2307/25148669

Borges, R. (2012). Tacit Knowledge Sharing Between IT Workers: The Role of Organisational Culture, Personality, And Social Environment. Management Research Review, 36(1), 89-108. https://Doi.Org/10.1108/ 01409171311284602 
IT Professionals in Sri Lanka

Connelly, C. E., \& Kevin Kelloway, E. (2003). Predictors of Employees' Perceptions of Knowledge Sharing Cultures. Leadership \& Organisation Development Journal, 24(5), 294-301. https://Doi.Org/10.1108/ 01437730310485815

Cronbach, L. J. (1951). Coefficient Alpha and the Internal Structure of Tests. Psychometrika 16(3).

Cummings, J. (2003). Knowledge Sharing: A Review of the Literature. https://ieg.worldbankgroup.org/sites/default/files/Data/reports/knowledge_eval_lite rature_review.pdf.

Davenport, T. H. (1994). Saving It's Soul: Human-Centered Information Management. Harvard Business Review, https://Hbr.Org/1994/03/Saving-Its-SoulHuman-Centered-Information-Management

Davenport, T. H., Prusak, L., \& Webber, A. (1998). Working Knowledge: How Organisations Manage What They Know. Working Knowledge, 16.

Delone, W. H., \& Mclean, E. R. (2003). The Delone and Mclean Model of Information Systems Success: A Ten-Year Update. Journal of Management Information Systems, 19(4), 9-30. https://Doi.Org/10.1080/07421222.2003. 11045748

Emerson, R. M. (1976). Social Exchange Theory. Annual Review of Sociology, 335-362.

Freeman, R. E. (1984). Strategic Management: A Stakeholder Approach. Cambridge University Press.

Freeman, R. E. (2010). Strategic Management: A Stakeholder Approach. Cambridge University Press.

Grubić-Nešić, L. (2015). The Influence of Demographic and Organisational Factors on Knowledge Sharing Among Employees in Organisations. Tehnicki VjesnikTechnical Gazette, 22(4), 1005-1010. https://Doi.Org/ 10.17559/Tv20141216213746

Hair, J., William, C., Black_Barry, J., \& Anderson, R. (1998). Multivariate Data Analysis.

Hall, H. (2001). Social_Exchange_For_Knowledge_Exchange. 
Han, B. M., \& Anantatmula, V. S. (2007). Knowledge Sharing in Large IT Organisations: A Case Study. Vine, 37(4), 421-439. https://Doi.Org/ 10.1108/03055720710838506

Hejase, H. (2014). Knowledge Sharing: Assessment of Factors Affecting Employee' Motivation and Behavior in the Lebanese Organisations. Journal of Scientific Research and Reports, 3(12), 1549-1593. https://Doi.Org/ $10.9734 / \mathrm{Jsrr} / 2014 / 8107$

Heymans, M., \& Eekhout, I. (2019). Chapter 2 Missing Data Evaluation | Book_Mi.Utf8.Md. https://Bookdown.Org/Mwheymans/Bookmi/Missing-DataEvaluation.Html

Ho, L., \& Kuo, T. (2013). How System Quality and Incentive Affect Knowledge Sharing. Industrial Management \& Data Systems, 113(7), 1048-1063. https://Doi.Org/10.1108/Imds-01-2013-0015

Hörisch, J., Freeman, R. E., \& Schaltegger, S. (2014). Applying Stakeholder Theory in Sustainability Management: Links, Similarities, Dissimilarities, and A Conceptual Framework. Organisation \& Environment, 27(4), 328-346. https://Doi.Org/10.1177/ 1086026614535786

Huang, L. K. (2015). Exploring Factors Affecting Top Management Support of It Implementation: A Stakeholder Perspective In Hospital. Journal of Information Technology Management 26(1), 15.

ICT Workforce Survey. (2019) Retrieved from https://www.icta.lk/ projects/national-it-bpm-workforce-survey-2019/.

Ismail, M. B., \& Yusof, Z. M. (2009). Demographic Factors and Knowledge Sharing Quality among Malaysian Government Officers. Communications of the IBIMA,9, 8 .

Jain, D. K. K., Sandhu, M. S., \& Sidhu, G. K. (2007). Knowledge Sharing Among Academic Staff: A Case Study of Business Schools In Klang Valley, Malaysia. JASA 2.

Kaewchur, O., \& Phusavat, K. (2016). Key Factors Influencing Knowledge Sharing. International Journal of Humanities and Management Sciences, 4(3), 5.

Kaiser, H. F. (1974). An Index of Factorial Simplicity. Psychometrika, 39(1), 3136. https://Doi.Org/10.1007/Bf02291575 


\section{IT Professionals in Sri Lanka}

Kanaan, D. R. (2013). The Impact of Knowledge Sharing Enablers on Knowledge Sharing Capability: An Empirical Study on Jordanian Telecommunication Firms. European Scientific Journal .9(22).

Kaplan, R., \& David, N. (2006, March). How to Implement a New Strategy without Disrupting Your Organisation. https://hbr.Org/2006/03/How-To-Implement-ANew-Strategy-Without-Disrupting-Your-Organisation

Kim, S., \& Lee, H. (2004). Organisational Factors Affecting Knowledge Sharing Capabilities In E-Government: An Empirical Study. Knowledge Management In Electronic Government,3035,281-293. https://Doi.Org/ 10.1007/978-3-540-24683$1 \_28$

Kim, S., \& Lee, H. (2006). The Impact Of Organisational Context And Information Technology On Employee Knowledge- Sharing Capabilities. Public Administration Review, 66(3), 370-385.

Krejcie, R. V., \& Morgan, D. W. (1970). Determining Sample Size For Research Activities. Educational and Psychological Measurement, 30(3), 607-610. https://Doi.Org/10.1177/001316447003000308

Kulkarni, U. R., Ravindran, S., \& Work(S), R. F. R. (2007). A Knowledge Management Success Model: Theoretical Development and Empirical Validation. Journal of Management Information Systems, 23(3), 309-347.

Labour Force Survey-Annual Report. (, 2018).

Lee, D.-J., \& Ahn, J.-H. (2007). Reward Systems for Intra-Organisational Knowledge Sharing. European Journal of Operational Research, 180(2), 938-956. https://Doi.Org/10.1016/J.Ejor.2006.03.052

Lee, H., \& Choi, B. (2003). Knowledge Management Enablers, Processes, and Organisational Performance: An Integrative View and Empirical Examination. Journal of Management Information Systems, 20(1), 179-228. https://Doi.Org/ 10.1080/07421222.2003.11045756

Lee, J.-C., Shiue, Y.-C., \& Chen, C.-Y. (2016). Examining The Impacts of Organisational Culture And Top Management Support of Knowledge Sharing on The Success of Software Process Improvement. Computers in Human Behavior, 54, 462-474. https://Doi.Org/10.1016/J.Chb.2015.08.030 
Leonard, D., \& Sensiper, S. (1998). The Role of Tacit Knowledge in Group Innovation. California Management Review, 40(3), 112-132. https://Doi.Org/10.2307/41165946

Lin, H. (2007). Knowledge Sharing and Firm Innovation Capability: An Empirical Study. International Journal of Manpower, 28(3/4), 315-332. https://Doi.Org/10.1108/01437720710755272

Lin, H.-F. (2006). Impact of Organisational Support on Organisational Intention to Facilitate Knowledge Sharing. Knowledge Management Research \& Practice, 4(1), 26-35. https://Doi.Org/10.1057/Palgrave.Kmrp. 8500083

Lin, H.-F. (2011). Antecedents of the Stage-Based Knowledge Management Evolution. Journal of Knowledge Management. https://Doi.Org/10.1108/ 13673271111108747

Maltz, E., \& Kohli, A. K. (2000). Reducing Marketing's Conflict with Other Functions: The Differential Effects of Integrating Mechanisms. Journal of the Academy of Marketing Science, 28(4), 479. https://Doi.Org/10.1177/ 0092070300284002

Marouf, L. (2015). Employee Perception of the Knowledge Sharing Culture in Kuwaiti Companies: Effect of Demographic Characteristics. 25(2), 16.

Masa'deh Ra'ed, Hamdi, A., Maqableh, M. M., \& Huda, K. (2013). An Empirical Study of Antecedents and Outcomes of Knowledge Sharing Capability in Jordanian Telecommunication Firms: A Structural Equation Modeling Approach. Life Science Journal 2013,10(4).

National Export Strategy of Sri Lanka 2018-2022.(,2018).https:// www.Srilankabusiness.com/pdf/nes/Sri-Lanka-nes-4-3-web.Pdf)

Neely, A. (1998). Business Performance Measurement: Theory and Practice. 382.

Nelson, R. R., Todd, P. A., \& Wixom, B. H. (2005). Antecedents of Information and System Quality: An Empirical Examination within the Context of Data Warehousing. Journal of Management Information Systems, 21(4), 199-235. https://Doi.Org/ 10.1080/ 07421222.2005.11045823

Niekerk, M. V., \& Getz, D. (2019). Applying Stakeholder Theory to the Management Functions.https://www.goodfellowpublishers.com/free_files/Chapter \%204-f5b33fd 0155 95cda6ecd94be11556570.pdf 


\section{IT Professionals in Sri Lanka}

Nonaka, I., Ryoko Toyama, \& Konno, N. (2000). Seci, Ba And Leadership: A Uni®Ed Model Of Dynamic Knowledge Creation. Long Range Planning, 33, 30.

Noor, N. M., \& Salim, J. (2011). Factors Influencing Employee Knowledge Sharing Capabilities. International Journal Of Computer Science Issues, 8(4)

Ojha, Abhoy, K. (2005). Impact of Team Demography on Knowledge Sharing in Software Project Teams. 12(3), 67-78.

Okyere-Kwakye. (2011). Individual Factors and Knowledge Sharing. American Journal of Economics and Business Administration, 3(1), 66-72. https://Doi.Org/10.3844/Ajebasp.2011.66.72

Ong, T. S., \& Teh, B. H. (2012). Reward System and Performance within Malaysian Manufacturing Companies. World Applied Sciences Journal.19(7).

Osborne, J. W., \& Waters, E. (2017). Four Assumptions Of Multiple Regression That Researchers Should Always Test. Practical Assessment, Research, and Evaluation, 8(2).

Pallant, J. (2011). SPSS Survival Manual. https://Doi.Org/ 10.4324/ 9781003117407

Pangil, F., \& Nasurdin, A. M. (2008). Demographics Factors and Knowledge Sharing Behavior among R\&D Employees. 6.

Pee, L., \& Kankanhalli, A. (2009). Interactions among Factors Influencing Knowledge Management in Public-Sector Organisations: A Resource-Based View. Government Information Quarterly.33 (1).

Pushpamali, N.N.C. (2015). A Study Of The Organisational Culture For Knowledge Sharing in Selected Bank Branches. 161-176. https://Pdfs.Semanticscholar.Org/4a32/3c79c203d71564cc01df69e0714c4b e2a1bc.Pdf?_Ga=2.95268828.1160262132.15886111211415851994. 1528433437

Ranasinghe, S., \& Gamini, L. P. S. (2008). Knowledge Sharing Among Academics In An Odl Context: The Case Of The Open University Of Sri Lanka. Journal of Humanities And Social Sciences, 4, (16).

Razak, N. A., Pangil, F., Zin, M. L. M., Yunus, N. A. M., \& Asnawi, N. H. (2016). Theories Of Knowledge Sharing Behavior In Business Strategy. Procedia Economics and Finance, 37, 545-553. https://Doi.Org/ 10.1016/S22125671(16)30163-0 
Saunders, M. N. K., Lewis, P., \& Thornhill, A. (2009). Research Methods for Business Students (5th Ed). Prentice Hall.

Singh Sandhu, M., Kishore Jain, K.,\& Umi Kalthom Bte Ahmad, I.(2011). Knowledge Sharing Among Public Sector Employees: Evidence From Malaysia.International Journal Of Public Sector Management, 24(3), 206-226. https://Doi.Org/10.1108/09513551111121347

Tan, C. N.-L. (2016a). Enhancing Knowledge Sharing And Research Collaboration Among Academics: The Role Of Knowledge Management. Higher Education, 71(4), 525-556. https://Doi.Org/10.1007/S10734-015-9922-6

Tan, C. N.-L., \& Md. Noor, S. (2013). Knowledge Management Enablers, Knowledge Sharing And Research Collaboration: A Study Of Knowledge Management At Research Universities In Malaysia. Asian Journal of Technology Innovation, 21(2), 251-276. https://Doi.Org/10.1080/ 19761597.2013.866314

Tan, H. H., \& Zhao, B. (2003). Individual- And Perceived Contextual-Level Antecedents Of Individual Technical Information Inquiry In Organisations. The Journal of Psychology, 137(6), 597-621. https://Doi.Org/_10.1080/00223980309600637

Tan, N. L. (2010). Motivational Factors In Influencing Knowledge Sharing Among Banks In Malaysia. International Research Journal of Finance and Economics 44, 12.

Tan, T. L., \& Trang, D. T. D. (2017). The Effects Of Demographic Variables On Knowledge Sharing Behaviour. The Journal Economic, 22(9) 10.

Wade, \& Hulland. (2004). Review: The Resource-Based View And Information Systems Research: Review, Extension, And Suggestions For Future Research. MIS Quarterly, 28(1), 107. https://Doi.Org/ 10.2307/25148626

Wang, S., \& Noe, R. (2010). Knowledge Sharing: A Review And Directions For Future Research. Human Resource Management Review. 20(2) 115-131.

Wickramasinghe, V., \& Widyaratne, R. (2012). Effects of Interpersonal Trust, Team Leader Support, Rewards, And Knowledge Sharing Mechanisms on Knowledge Sharing In Project Teams. VINE. 42 (10).

Xue, J., \& Zhang, Z. (2010). Research on the Relationship between Knowledge Management Infrastructure, Knowledge Sharing and Knowledge Management Performance. 2010 International Conference on Management and Service Science, 1-4. https://Doi.Org/10.1109/Icmss.2010.5577022 
Figure 1: Preliminary survey on recognition

Do you agree that by sharing your knowledge you will be able to obtain recognition in your organization

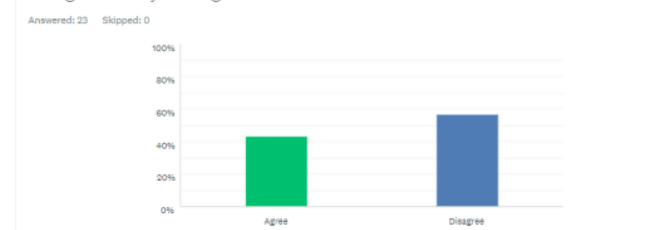

Source: Preliminary Survey Data

Figure 3: Preliminary survey on rewards

Do you agree that by sharing your knowledge you will be rewarded by your organization?

Answered: 23 Shipped: 0

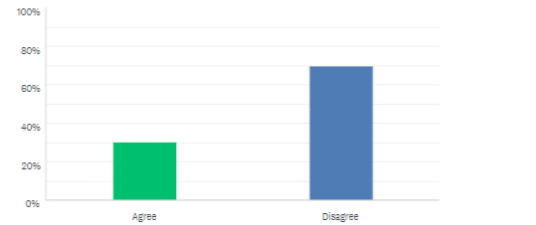

Source: Preliminary Survey Data

Figure 5: Preliminary survey on opportunities to access new knowledge

How often do you have the opportunity to attend training courses, conferences etc
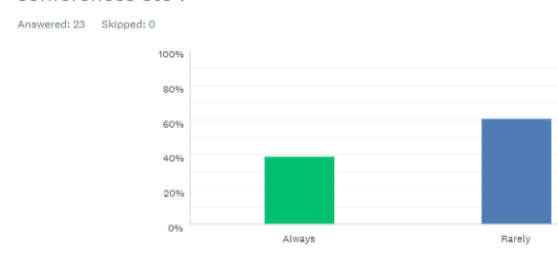

Source: Preliminary Survey Data
Figure 2: Preliminary survey on knowledge sharing

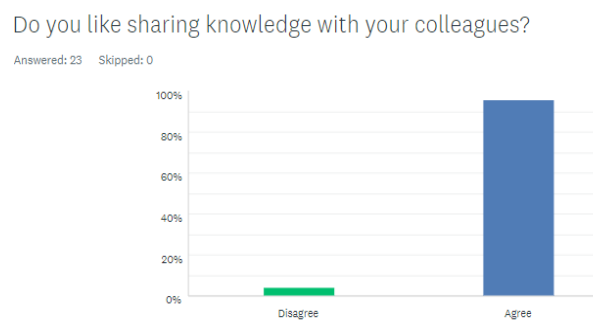

Source: Preliminary Survey Data

Figre 4 : Preliminary survey on opportunities to share knowledge

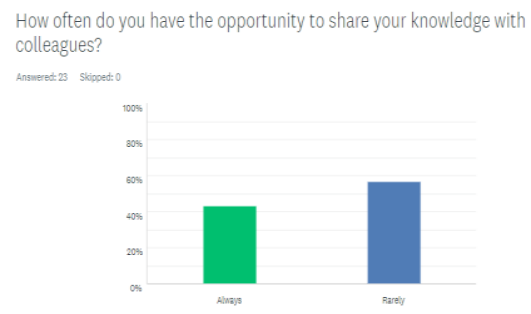

Source: Preliminary Survey Data 
Figure 6: Conceptual Framework of this study

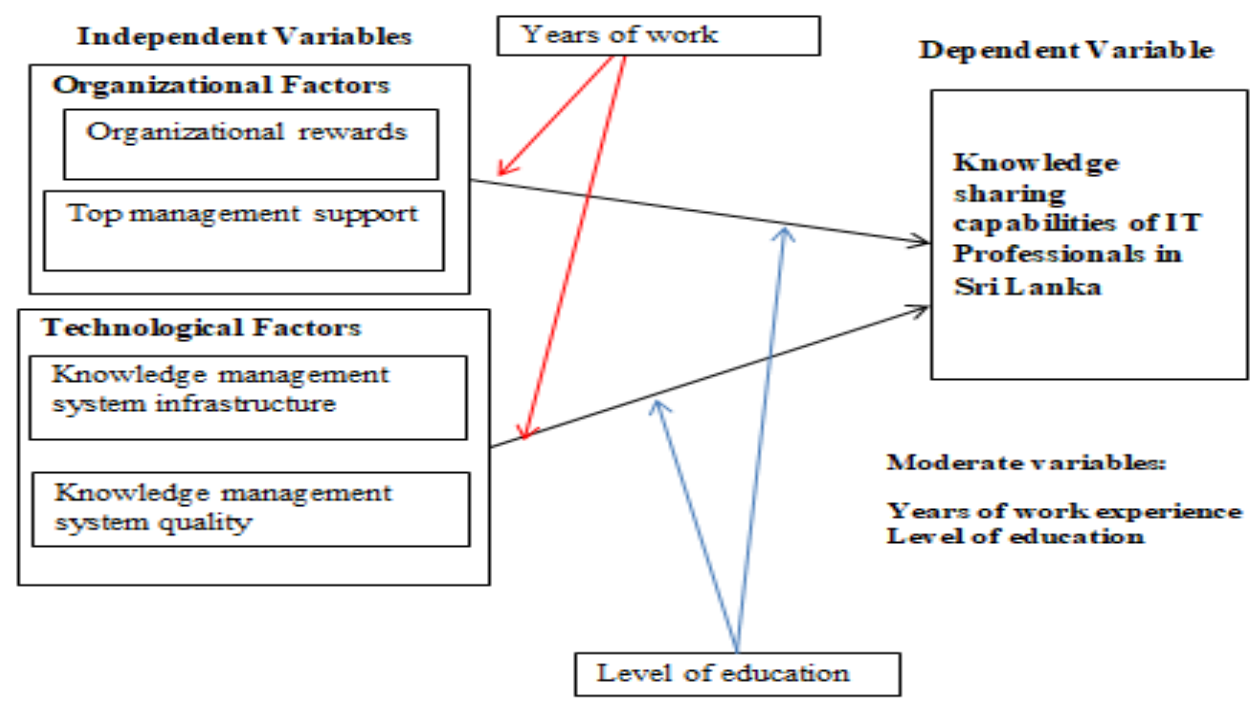

Source: Researchers Compiled

Table 1 : Literature review on factors which influence in knowledge sharing capabilities

\begin{tabular}{|l|l|l|}
\hline $\begin{array}{l}\text { Globally \& Sri } \\
\text { Lankan context }\end{array}$ & Title of the study & $\begin{array}{l}\text { Factors related to knowledge sharing } \\
\text { and knowledge sharing capabilities }\end{array}$ \\
\hline $\begin{array}{l}\text { (Kaewchur and } \\
\text { Phusavat, 2016) }\end{array}$ & $\begin{array}{l}\text { Key Factors Influencing } \\
\text { Knowledge Sharing }\end{array}$ & $\begin{array}{l}\text { Influence knowledge sharing trust, } \\
\text { Motivation, Leadership, IT, } \\
\text { Organisational culture }\end{array}$ \\
\hline (Kim and Lee, & $\begin{array}{l}\text { The Impact of } \\
\text { Organizational Context } \\
\text { and IT on Employees } \\
\text { knowledge sharing } \\
\text { capabilities. }\end{array}$ & $\begin{array}{l}\text { Rewards, social networks, IT and end- } \\
\text { user focus influences on knowledge } \\
\text { sharing capabilities. Work experience } \\
\text { not influenced by knowledge sharing } \\
\text { capabilities. }\end{array}$ \\
\hline $\begin{array}{l}\text { (Noor and } \\
\text { Salim, 2011) }\end{array}$ & $\begin{array}{l}\text { Factors Influencing } \\
\text { Employee Knowledge } \\
\text { Sharing Capabilities in } \\
\text { Electronic Government } \\
\text { Agencies in Malaysia. }\end{array}$ & $\begin{array}{l}\text { Rewards, ICT infrastructure, } \\
\text { organisational culture, individual } \\
\text { factors influence knowledge sharing } \\
\text { capabilities. }\end{array}$ \\
\hline
\end{tabular}


IT Professionals in Sri Lanka

\begin{tabular}{|c|c|c|}
\hline $\begin{array}{l}\text { (Kim and Lee, } \\
\text { 2004) }\end{array}$ & $\begin{array}{l}\text { Organisational Factors } \\
\text { Affecting Knowledge } \\
\text { Sharing Capabilities in E- } \\
\text { government: An Empirical } \\
\text { Study }\end{array}$ & $\begin{array}{l}\text { A statistically significant impact of } \\
\text { enjoyment in helping others, } \\
\text { knowledge self-efficacy, organisational } \\
\text { rewards, and ICT use on knowledge } \\
\text { sharing capability }\end{array}$ \\
\hline (Kanaan, 2013) & $\begin{array}{l}\text { The Impact Of Knowledge } \\
\text { Sharing Enablers On } \\
\text { Knowledge Sharing } \\
\text { Capability: An Empirical } \\
\text { Study On Jordanian } \\
\text { Telecommunication Firms }\end{array}$ & $\begin{array}{l}\text { Knowledge sharing enablers } \\
\text { (enjoyment in helping others, } \\
\text { knowledge self-efficacy, top } \\
\text { management support, organisational } \\
\text { rewards, and ICT use) would increase } \\
\text { the knowledge sharing capabilities. }\end{array}$ \\
\hline (Hejase, 2014) & $\begin{array}{l}\text { Knowledge Sharing: } \\
\text { Assessment of Factors } \\
\text { affecting Employee's } \\
\text { motivation and behavior } \\
\text { in the Lebanese } \\
\text { organisations }\end{array}$ & $\begin{array}{l}\text { Influencing factors of knowledge } \\
\text { sharing, trust, management support, } \\
\text { culture and psychological ownership of } \\
\text { knowledge. }\end{array}$ \\
\hline (Tan, 2016a) & $\begin{array}{l}\text { Enhancing knowledge } \\
\text { sharing and research } \\
\text { collaboration among } \\
\text { academics :the role of KM }\end{array}$ & $\begin{array}{l}\text { Top management support, } \\
\text { communication, trust, rewards, KMS } \\
\text { influence knowledge sharing. }\end{array}$ \\
\hline (H. Lin, 2007) & $\begin{array}{l}\text { Knowledge sharing and } \\
\text { firm innovation capability: } \\
\text { an empirical study }\end{array}$ & $\begin{array}{l}\text { Top management support, rewards, } \\
\text { self-efficacy influences knowledge } \\
\text { sharing but not technology. }\end{array}$ \\
\hline $\begin{array}{l}\text { (Abdul-Cader } \\
\text { and Johar, 2016) }\end{array}$ & $\begin{array}{l}\text { A study of knowledge } \\
\text { contribution through EKR } \\
\text { among Sri Lankan IT } \\
\text { professionals. }\end{array}$ & $\begin{array}{l}\text { Rewards and image influence the } \\
\text { knowledge sharing. }\end{array}$ \\
\hline $\begin{array}{l}\text { (Masa'deh,Ghari } \\
\text { beh, Maqableh } \\
\text { and } \\
\text { Karajeh,2013) }\end{array}$ & $\begin{array}{l}\text { An Empirical Study of } \\
\text { Antecedents and } \\
\text { Outcomes of Knowledge } \\
\text { Sharing Capability in } \\
\text { Jordanian } \\
\text { Telecommunication } \\
\text { Firms: A Structural } \\
\text { Equation Modeling } \\
\text { Approach }\end{array}$ & $\begin{array}{l}\text { Top management support, } \\
\text { organisational rewards, enjoyment in } \\
\text { helping others and ICT use influence on } \\
\text { employees' knowledge sharing } \\
\text { capability }\end{array}$ \\
\hline $\begin{array}{l}\text { (Dharmasiri and } \\
\text { Kodeeswaran, } \\
\text { 2011) }\end{array}$ & $\begin{array}{l}\text { A study of knowledge } \\
\text { sharing practices of Civil } \\
\text { Society Organisations in } \\
\text { SL. }\end{array}$ & $\begin{array}{l}\text { Individual capability, time, nature of } \\
\text { the job, nature of the knowledge, IT, } \\
\text { training influence knowledge sharing. }\end{array}$ \\
\hline
\end{tabular}




\begin{tabular}{|l|l|l|}
\hline $\begin{array}{l}\text { (Ranasingh and } \\
\text { Gamini, 2008) }\end{array}$ & $\begin{array}{l}\text { Knowledge sharing among } \\
\text { academics in ODL } \\
\text { context: the case study of } \\
\text { OUSL. }\end{array}$ & $\begin{array}{l}\text { Rewards and culture influence } \\
\text { knowledge sharing. }\end{array}$ \\
\hline $\begin{array}{l}\text { (Wickramasingh } \\
\text { Widyaratne, } \\
\text { 2012) }\end{array}$ & $\begin{array}{l}\text { Effects of interpersonal } \\
\text { trust, team leader support, } \\
\text { rewards, and knowledge } \\
\text { haring mechanisms on } \\
\text { knowledge sharing in } \\
\text { project teams. }\end{array}$ & $\begin{array}{l}\text { Trust and rewards influence knowledge } \\
\text { sharing. }\end{array}$ \\
\hline
\end{tabular}

Source: Researchers Compiled

Table 2: Operationalisation of the Constructs

\begin{tabular}{|l|l|l|l|}
\hline Concept & Indicators & $\begin{array}{l}\text { Questions with 5 point } \\
\text { likert scale }\end{array}$ & References \\
\hline $\begin{array}{l}\text { Knowledg } \\
\text { e sharing } \\
\text { capabilitie } \\
\text { s }\end{array}$ & $\begin{array}{l}\text { Degree of sharing } \\
\text { knowledge of an } \\
\text { individual } \\
\text { (willingness) }\end{array}$ & $\begin{array}{l}\text { I like to share my know-how, } \\
\text { effective information, and } \\
\text { knowledge with my other } \\
\text { colleagues. }\end{array}$ & (Kim and \\
& $\begin{array}{l}\text { Lee, 2006) } \\
\text { the knowledge of } \\
\text { others }\end{array}$ & $\begin{array}{l}\text { The documents, information } \\
\text { and knowledge held by other } \\
\text { departments within the } \\
\text { organisation could be } \\
\text { accessed easily. }\end{array}$ & \\
\cline { 2 - 4 } & $\begin{array}{l}\text { Willingness to share } \\
\text { the new knowledge }\end{array}$ & $\begin{array}{l}\text { I like to share the knowledge } \\
\text { gained from conferences }, \\
\text { trainings, workshops }, \\
\text { seminars etc. }\end{array}$ & (Tan, \\
\cline { 2 - 4 } & $\begin{array}{l}\text { Level of } \\
\text { communication } \\
\text { among the teams }\end{array}$ & $\begin{array}{l}\text { Employees of my } \\
\text { organisation like to cooperate } \\
\text { or communicate with each } \\
\text { other teams or groups for } \\
\text { sharing information and } \\
\text { knowledge. }\end{array}$ & Lee, 2006) \\
\hline
\end{tabular}


IT Professionals in Sri Lanka

\begin{tabular}{|c|c|c|c|}
\hline \multirow[t]{4}{*}{$\begin{array}{l}\text { Organisati } \\
\text { onal } \\
\text { rewards }\end{array}$} & $\begin{array}{l}\text { Degree of receiving } \\
\text { extrinsic incentive - } \\
\text { salary increment, } \\
\text { when knowledge is } \\
\text { shared. }\end{array}$ & $\begin{array}{l}\text { I would like to receive a } \\
\text { higher salary in return for } \\
\text { sharing my knowledge. }\end{array}$ & \multirow[t]{4}{*}{$\begin{array}{l}\text { (H. Lin, } \\
\text { 2007) }\end{array}$} \\
\hline & $\begin{array}{l}\text { Degree of receiving } \\
\text { extrinsic incentive - } \\
\text { promotion, when } \\
\text { knowledge is shared. }\end{array}$ & $\begin{array}{l}\text { I would like to receive } \\
\text { increased promotion } \\
\text { opportunities in return for } \\
\text { sharing my knowledge. }\end{array}$ & \\
\hline & $\begin{array}{l}\text { Degree of receiving } \\
\text { extrinsic incentive - } \\
\text { job security, when } \\
\text { knowledge is shared. }\end{array}$ & $\begin{array}{l}\text { I would like to receive } \\
\text { increased job security in } \\
\text { return for sharing my } \\
\text { knowledge. }\end{array}$ & \\
\hline & $\begin{array}{l}\text { Degree of receiving } \\
\text { extrinsic incentive - } \\
\text { bonus, when } \\
\text { knowledge is shared. }\end{array}$ & $\begin{array}{l}\text { I would like to receive a } \\
\text { higher bonus in return for } \\
\text { sharing my knowledge. }\end{array}$ & \\
\hline \multirow[t]{4}{*}{$\begin{array}{l}\text { Top } \\
\text { managem } \\
\text { ent } \\
\text { support }\end{array}$} & $\begin{array}{l}\text { Level of } \\
\text { encouragement given } \\
\text { by the top } \\
\text { management }\end{array}$ & $\begin{array}{l}\text { Top management considers } \\
\text { that encouraging knowledge } \\
\text { sharing with colleagues is } \\
\text { beneficial. }\end{array}$ & \multirow[t]{2}{*}{$\begin{array}{l}\text { (H. Lin, } \\
\text { 2007) }\end{array}$} \\
\hline & $\begin{array}{l}\text { Level of willingness } \\
\text { (top management's ) } \\
\text { on knowledge } \\
\text { sharing }\end{array}$ & $\begin{array}{l}\text { Top management always } \\
\text { support and encourage } \\
\text { employees to share their } \\
\text { knowledge with colleagues. }\end{array}$ & \\
\hline & $\begin{array}{l}\text { Level of providing } \\
\text { necessary resources } \\
\text { to share the } \\
\text { knowledge by the top } \\
\text { management. }\end{array}$ & $\begin{array}{l}\text { Top management provides } \\
\text { most of the necessary help } \\
\text { and resources to enable } \\
\text { employees to share } \\
\text { knowledge. }\end{array}$ & \multirow[t]{2}{*}{$\begin{array}{l}\text { (H.-F. Lin, } \\
\text { 2011) }\end{array}$} \\
\hline & $\begin{array}{l}\text { Level of top } \\
\text { management's } \\
\text { passion about } \\
\text { knowledge sharing. }\end{array}$ & $\begin{array}{l}\text { Top management is keen to } \\
\text { see that the employees are } \\
\text { happy to share their } \\
\text { knowledge with colleagues. }\end{array}$ & \\
\hline $\begin{array}{l}\text { Knowledg } \\
\text { e } \\
\text { managem } \\
\text { ent system } \\
(\text { KMS })\end{array}$ & $\begin{array}{l}\text { Level of accessibility } \\
\text { of the KMS }\end{array}$ & $\begin{array}{l}\text { My organisation uses a KM } \\
\text { system that allows the } \\
\text { employees in my } \\
\text { organisation to access } \\
\text { necessary knowledge. }\end{array}$ & $\begin{array}{l}\text { (Tan, } \\
\text { 2016a) }\end{array}$ \\
\hline
\end{tabular}




\begin{tabular}{|c|c|c|c|}
\hline \multirow[t]{3}{*}{$\begin{array}{l}\text { infrastruct } \\
\text { ure }\end{array}$} & $\begin{array}{l}\text { Level of searching } \\
\text { ability of the KMS }\end{array}$ & $\begin{array}{l}\text { My organisation uses a KM } \\
\text { system that allows employees } \\
\text { in my organisation to search } \\
\text { necessary knowledge. }\end{array}$ & \\
\hline & $\begin{array}{l}\text { Level of } \\
\text { communication of the } \\
\text { KM system }\end{array}$ & $\begin{array}{l}\text { My organisation uses a KM } \\
\text { system that allows employees } \\
\text { in my organisation to } \\
\text { communicate with each } \\
\text { other. }\end{array}$ & \\
\hline & $\begin{array}{l}\text { Degree of } \\
\text { collaboration of the } \\
\text { KMS. }\end{array}$ & $\begin{array}{l}\text { My organisation uses a KM } \\
\text { system that allows employees } \\
\text { in organisation to collaborate } \\
\text { with each other. }\end{array}$ & \\
\hline \multirow{4}{*}{$\begin{array}{l}\text { Knowledg } \\
\text { e } \\
\text { managem } \\
\text { ent system } \\
\text { quality }\end{array}$} & $\begin{array}{l}\text { Degree of relevance } \\
\text { of the knowledge } \\
\text { provided by the KMS }\end{array}$ & $\begin{array}{l}\text { The knowledge provided by } \\
\text { the KM system at my } \\
\text { organisation is relevant to my } \\
\text { day to day work. }\end{array}$ & \multirow[t]{4}{*}{$\begin{array}{l}\text { (Tan, } \\
\text { 2016a) }\end{array}$} \\
\hline & $\begin{array}{l}\text { Degree of accuracy } \\
\text { of the knowledge } \\
\text { provided by the KMS }\end{array}$ & $\begin{array}{l}\text { The knowledge provided by } \\
\text { the KM system at my } \\
\text { organisation is accurate and } \\
\text { up-to-date. }\end{array}$ & \\
\hline & $\begin{array}{l}\text { Degree of } \\
\text { dependability of the } \\
\text { KMS. }\end{array}$ & $\begin{array}{l}\text { The operation of the KM } \\
\text { system at my organisation is } \\
\text { dependable. }\end{array}$ & \\
\hline & $\begin{array}{l}\text { Degree of availability } \\
\text { of the KMS }\end{array}$ & $\begin{array}{l}\text { The KM system at my } \\
\text { organisation makes } \\
\text { knowledge easy to access. }\end{array}$ & \\
\hline
\end{tabular}

Source: Researchers Compiled 
Factors Associated with Knowledge Sharing Capabilities of

\section{IT Professionals in Sri Lanka}

Table 3: Results of the Pearson Correlations

\begin{tabular}{|c|c|c|c|c|c|c|}
\hline & & KSC & RWD & TMS & KMSI & \begin{tabular}{|l|}
$\mathbf{K M S}$ \\
$\mathbf{Q}$
\end{tabular} \\
\hline \multirow[t]{3}{*}{ KSCap } & Pearson Correlation & 1 & $.148 * *$ & . $545^{*}$ & $.500 * *$ & $.533 * *$ \\
\hline & Sig. (2-tailed) & & .004 & .000 & .000 & .000 \\
\hline & $\mathbf{N}$ & 368 & 368 & 368 & 368 & 368 \\
\hline \multirow{3}{*}{$\begin{array}{l}\text { OrgRewar } \\
\text { d }\end{array}$} & Pearson Correlation & $.148 * *$ & 1 & .051 & $.214 * *$ & $.169 * *$ \\
\hline & Sig. (2-tailed) & .004 & & .325 & .000 & .001 \\
\hline & $\mathbf{N}$ & 368 & 368 & 368 & 368 & 368 \\
\hline \multirow{3}{*}{$\begin{array}{l}\text { TopMgtS } \\
\text { up }\end{array}$} & Pearson Correlation & $.545 * *$ & .051 & 1 & $.608 * *$ & $.626 * *$ \\
\hline & Sig. (2-tailed) & .000 & .325 & & .000 & .000 \\
\hline & $\mathbf{N}$ & 368 & 368 & 368 & 368 & 368 \\
\hline \multirow[t]{3}{*}{$\begin{array}{l}\text { KMSInfra } \\
\text { st }\end{array}$} & Pearson Correlation & $.157 * *$ & $.214 * *$ & $\begin{array}{l}.608 * \\
*\end{array}$ & 1 & $.906 * *$ \\
\hline & Sig. (2-tailed) & .000 & .000 & .000 & & .000 \\
\hline & $\mathbf{N}$ & 368 & 368 & 368 & 368 & 368 \\
\hline \multirow[t]{3}{*}{ KMSquali } & Pearson Correlation & $.533 * *$ & $.169 * *$ & $\begin{array}{l}.626 * \\
*\end{array}$ & $.906 * *$ & 1 \\
\hline & Sig. (2-tailed) & .000 & .001 & .000 & .000 & \\
\hline & $\mathbf{N}$ & 368 & 368 & 368 & 368 & 368 \\
\hline
\end{tabular}

**. Correlation is significant at the 0.01 level (2-tailed).

Source: Survey Data 
Table 4: Multiple Regression Coefficients

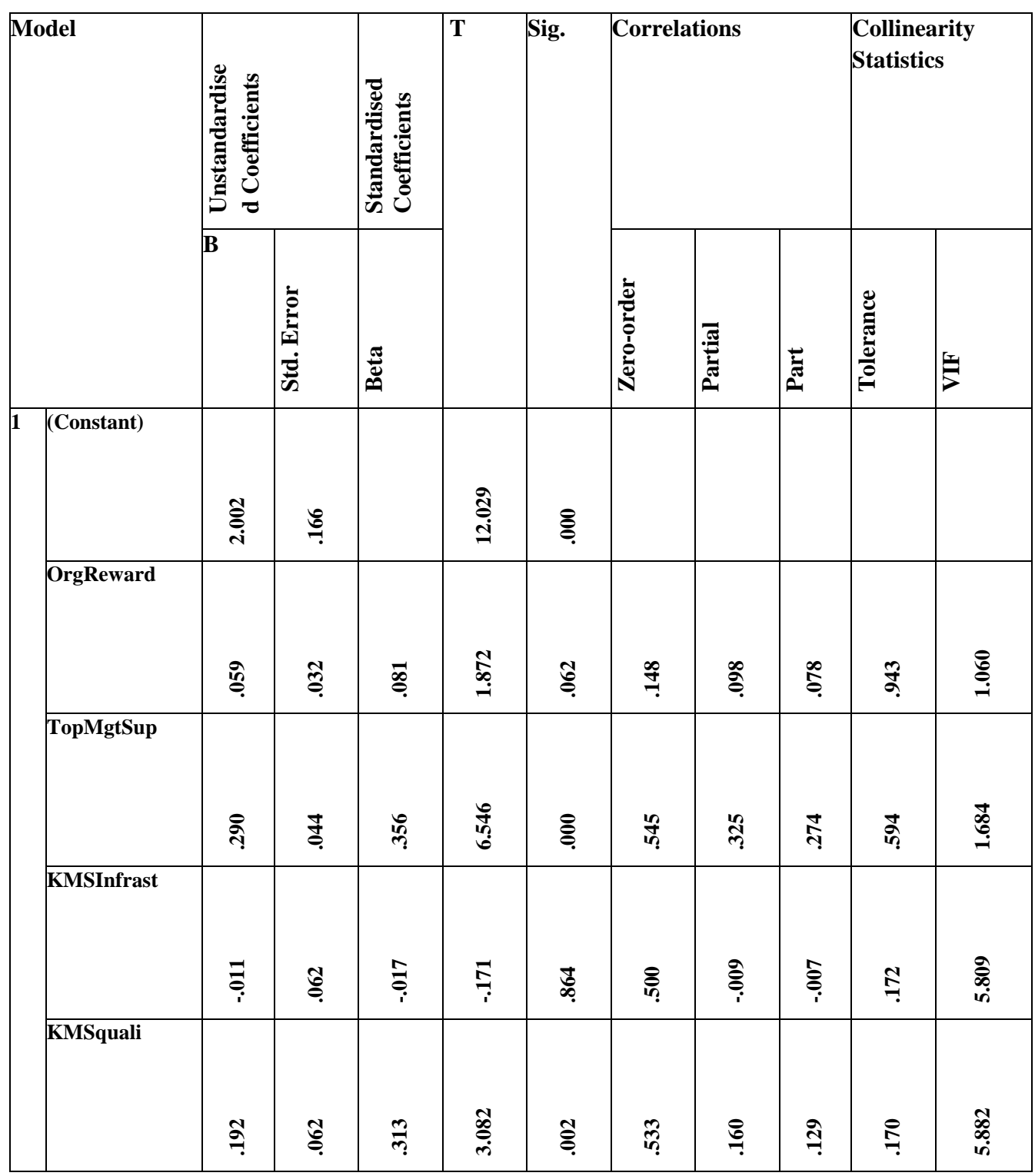

a. Dependent Variable: KSCapa, $\mathrm{N}=368, \mathrm{p}<.05$

Source: Survey Data 
IT Professionals in Sri Lanka

Table 5: Summary of Multiple Regression and Hierarchical Multiple Regression

\begin{tabular}{|c|c|c|c|c|c|}
\hline Variable & 递 & Sig & $\begin{array}{l}\text { Moderate } \\
\text { Variable }\end{array}$ & $\begin{array}{r}\text { Standardised } \\
\text { Coefficients } \\
\text { with the } \\
\text { moderate } \\
\text { variable }\end{array}$ & $\begin{array}{l}\text { Sig with } \\
\text { the } \\
\text { average } \\
\text { variable }\end{array}$ \\
\hline \multirow{2}{*}{$\begin{array}{l}\text { Organisation } \\
\text { al Rewards }\end{array}$} & \multirow{2}{*}{.081} & \multirow{2}{*}{.062} & $\begin{array}{l}\text { Level of } \\
\text { Education }\end{array}$ & 0.164 & 0.002 \\
\hline & & & $\begin{array}{l}\text { Years of } \\
\text { Experience }\end{array}$ & 0.156 & 0.003 \\
\hline \multirow{2}{*}{$\begin{array}{l}\text { Top } \\
\text { Management } \\
\text { Support }\end{array}$} & \multirow{2}{*}{.356} & \multirow[t]{2}{*}{.000} & $\begin{array}{l}\text { Level of } \\
\text { Education }\end{array}$ & 0.543 & 0.000 \\
\hline & & & $\begin{array}{l}\text { Years of } \\
\text { Experience }\end{array}$ & 0.544 & 0.000 \\
\hline \multirow{2}{*}{$\begin{array}{l}\text { KM System } \\
\text { Infrastructur } \\
\text { e }\end{array}$} & \multirow{2}{*}{$\begin{array}{l}- \\
.017\end{array}$} & \multirow{2}{*}{.864} & $\begin{array}{l}\text { Level of } \\
\text { Education }\end{array}$ & 0.504 & 0.000 \\
\hline & & & $\begin{array}{l}\text { Years of } \\
\text { Experience }\end{array}$ & 0.499 & 0.000 \\
\hline \multirow{2}{*}{$\begin{array}{l}\text { KM System } \\
\text { Quality }\end{array}$} & \multirow{2}{*}{.313} & \multirow{2}{*}{.002} & $\begin{array}{l}\text { Level of } \\
\text { Education }\end{array}$ & 0.537 & 0.000 \\
\hline & & & $\begin{array}{l}\text { Years of } \\
\text { Experience }\end{array}$ & 0.533 & 0.000 \\
\hline
\end{tabular}

$\mathrm{p}<.05$,

Source: Survey Data 
Table 6: The Results of Hierarchical Multiple Regression Analysis

\begin{tabular}{|c|c|c|c|c|c|c|c|c|c|c|}
\hline \multirow[t]{2}{*}{ Variable } & \multirow[b]{2}{*}{ 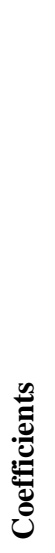 } & \multirow[b]{2}{*}{$\stackrel{900}{20}$} & \multicolumn{2}{|c|}{$\begin{array}{l}\text { Degree } \\
\text { level }\end{array}$} & \multicolumn{2}{|c|}{$\begin{array}{l}\text { Postgrad } \\
\text { uate } \\
\text { Diploma } \\
\text { level }\end{array}$} & \multicolumn{2}{|c|}{$\begin{array}{l}\text { Less } \\
\text { than } \\
\text { ten } \\
\text { years } \\
\text { of work } \\
\text { experie } \\
\text { nce }\end{array}$} & \multicolumn{2}{|c|}{$\begin{array}{l}\text { More } \\
\text { than } \\
\text { ten } \\
\text { years } \\
\text { of } \\
\text { work } \\
\text { experie } \\
\text { nce }\end{array}$} \\
\hline & & & ن & $\ddot{\dot{D B}}$ & ن & $\ddot{\theta 0}$ & نُ & $\frac{\dot{0}}{20}$ & 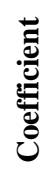 & $\dot{\theta 0}$ \\
\hline $\begin{array}{l}\text { Organisat } \\
\text { ional } \\
\text { Rewards }\end{array}$ & \&̊ & ֶै. & 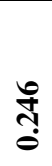 & ڤ્ڤ & ?ै & $\stackrel{\bar{\theta}}{\circ}$ & 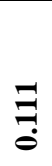 & ڤ્ڤે & กี & 气̊: \\
\hline $\begin{array}{l}\text { Top } \\
\text { Managem } \\
\text { ent } \\
\text { Support }\end{array}$ & ?ొ & ఏి & $\stackrel{?}{+}$ & 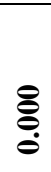 & $\stackrel{\vec{E}}{\overrightarrow{6}}$ & छ̊. & $\stackrel{\infty}{\stackrel{\leftrightarrow}{+}}$ & 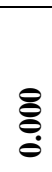 & 㕝 & ڤ్ర \\
\hline $\begin{array}{l}\text { KMS } \\
\text { Infrastru } \\
\text { cture }\end{array}$ & $\stackrel{5}{\circ}$ & ఫ্ & 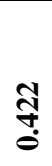 & ڤ્ڤ & $\begin{array}{l}\bar{n} \\
0 \\
0\end{array}$ & 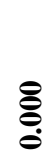 & ঙ্ণি & $\stackrel{0}{0}$ & है & $\stackrel{0}{0}$ \\
\hline $\begin{array}{l}\text { KMS } \\
\text { Quality }\end{array}$ & $\frac{m}{m}$ & $\tilde{\Xi}$ & $\stackrel{8}{:}$ & ڤ్ & $\stackrel{\bar{b}}{0}$ & $\stackrel{8}{0}$ & $\stackrel{\text { I }}{+}$ & 高 & 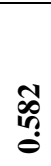 & ڤ̊ \\
\hline
\end{tabular}

$\mathrm{p}<.05$

Source: Survey Data 